\title{
An Ecosystem (ECO) Approach on Wisdom Societies and Sociotechnical Systems
}

\author{
Antonio José Balloni ${ }^{1}$, Adalberto Mantovani Martiniano de Azevedo ${ }^{2}$, \\ Marco Antonio Silveira ${ }^{1}$ \\ ${ }^{1}$ Center for Information Technology Renato Archer (CTI), Campinas, Brazil \\ ${ }^{2}$ Federal University of ABC, Santo André, Brazil \\ Email: antonio.balloni@cti.gov.br, adalberto.azevedo@ufabc.edu.br, marco.silveira@cti.gov.br
}

Received May $29^{\text {th }}$, 2012; revised July $10^{\text {th }}$, 2012; accepted August $13^{\text {th }}, 2012$

\begin{abstract}
This paper explores the challenges and expresses some reflections on information and Knowledge/Wise (KW) societies and Socio-technical Systems (SS) based on an Organizational Ecosystems (ECOs) approach. It considers the SS constituting KW societies as a set of heterogeneous and interactive actors and presents considerations on the challenges faced by an organizational Ecosystem (ECO), challenges that require organizations actions towards treatment of organizations as living beings inserted in ECOs, aiming to leverage organizational synergism and collaborative efforts; information partnership and collaborative relationships between ECOs members; a more fairly shared leadership, empowering bottom up processes on organizational ECOs decision making. It is presented a brief case regarding Brazil's Public Research and Development arrangement "National Institute of Science and Technology in Micro and Nano-electonic Systems” (NAMITEC), relating this initiative advances and problems in terms of multi-organizational cooperation and transference of technological knowledge to the productive sector and to society.
\end{abstract}

Keywords: Information Society; Knowledge Society; Wisdom Society; Socio-Technical Systems; Organizational Ecosystems; Public Research; Development Arrangements

\section{Introduction: From the Information and Knowledge/Wisdom Societies to Socio-Technical Systems}

In the 21 century, Information and Communication Technologies (ICTs) are redefining businesses concepts and operations. Customer service, integration of business operations, and strategies of product development, marketing and distribution depend totally on ICT: thus, ICT and its costs are increasingly making integral part of enterprise day-by-day and becoming critical for its success. However, many enterprises still believe that just the act of computerizing by spreading computers and printers throughout departmental units, connecting them in a network and installing applications systems, can fulfill the expected benefits: ICT technology without planning, management and effective action from knowledge/wisdom workers and, above all, without considering the Socio-technical Systems (SS) which are inserted in an organizational ECO composed by multiple and heterogeneous actors, does not bring any meaningful and sustainable contribution to the enterprise's success (Balloni, 2010).

The information wave which follows the agricultural wave and industrial wave in the 21st century triggers the rise of an information society, in which the creation, distribution, diffusion, use, integration and manipulation of information is the more significant economic, political, and cultural activity. This idea, society centered on information, is closely related to concepts such as: post-industrial society, post-fordism, post-modern society, knowledge society, tele-matic society, information revolution and network society.

The Knowledge Society (KS) is one in which knowledge becomes a major creative force. Economic, social, cultural, and all other human activities become dependent on a huge volume of information and knowledge. The knowledge societies are not a new occurrence: fishermen have long time ago shared the intuitive knowledge of predicting the weather for their community and his knowledge belonged as the social capital of that community. The difference, today, is the huge amount of information regarding the needs of an organizational ECO approach: the creation of wealth through knowledge-driven understanding of economic activities.

With ICT technologies, ECO knowledge societies are not constrained by geographic proximity, becoming de facto a network connected by the Internet (Sörlin and Vessuri, 2007). This phenomenon has been triggered by a combination of growth on internet/data storage capacity and decline in its operational costs (Willinger and Doyle, 2002; Chang, n.d.).

The Wisdom Society is a society whose citizens are able to make good judgment and choices, based on the information available. The ICT systems process cognitive units such as data, information, concepts, knowledge, and wisdom, which support human decision-making in societal activities (Targowski, 2003; Targowski, 2011).

\section{Technical, Socio-Technical and Organizational Systems and Ecosystems}

As it is widely known, the implementation of a new technology has been associated with problems often linked to resistance by the work force and failure to achieve the expected benefits (Balloni and Targowski, 2010). Tavistock Institute 
researchers indicate these problems occur due to the need to fit the technical system (such as an information system: software, hardware, databases and telecommunications) and the social system (peoples and procedures), which together made up an organization (Business Strategies, Rules and Processes), that influence and are influenced by a technical system of an information system (Akbari and Land, s.d.; Warne and Hart, 1996; Bostrom and Heinen, 1977).

The SCOT (Social Construction of Technology) approach (Pinch e Bijker, 1989) shows that the construction (selection and diffusion) of a socially accepted technological artifact is a social phenomenon, which depends on negotiations between stakeholders. This dependency \& negotiations shapes the technology variation and the selection processes. Eventually this leads to a consensual solution and to the customized adoption of a technology to actors' knowledge and interests.

The concepts of technological frame and inclusion by Bijker (1989) allow a deeper understanding of the SCOT approach. A technological frame consists in concepts and techniques used by a stakeholders' community aiming to solve specific problems, and contain the "rules of the game" for problem solving: the definition of the problem, resolution methods and solutions with satisfactory (acceptable) qualification. Thus, the technological frame is a combination of theories, tacit knowledge, engineering practices, test and consumption behavior.

The concept of large technological systems by Hughes (1989) defines social, political, economical and technical elements involved in the development and diffusion of technologies. Such systems are built by actors interested in advantages (monetary, spiritual, scientific, etc.) arising from the system development. These system builders set up complex technological systems which, while socially constructed, influence the format of society as its builders attempt to eliminate problems and uncertainties which could be bad for the system. Therefore, the technological system depends on its adaptation to the environment and on the intentional creation of favorable conditions. The system builder solves problems by actions in the social, political and technical spheres, trying to eliminate reverse salients, (as the author refers to them), that are system components not fitted to its expansion, such as technical problems and institutional barriers.

An organizational system will be able to maximize performance if the interdependency of these systems are explicitly recognized and designed for their sustainability leading to a balanced organizational ECO for a better economic performance of the organization.

Organizations performances are frequently the results of combined actions performed by several independent organizations, as in the case of collaborative arrangements for Research and Development. In such networked societies, the sociotechnical approach can be extended from the individual organization to the collection of organizations dependent on each other, defined here as an organizational ECO.

The approach of organizational ECOs (Kay, Regier, Boyle and Francis, 1999; Iansiti and Levien, 2004; Balloni, Resende and Targowski, 2012; Azevedo, Bueno, Balloni and Silveira, 2011) considers businesses networks as similar to biological ECOs, characterized by a large number of loosely and interdependent interconnected participants. The components of a business network share their fate with each other. If the ECO is healthy, individual species thrive (Iansiti and Levien, 2004).

By managing its organizational ECO, an organization is able to acquire external competences and resources of other organizations (been it data, information, concepts, knowledge or wisdom). This is especially important in cases where organizations aim to reach costly and complex objectives, which require the conjointly work of several organizations with different competences and resources, such as the research and development arrangement described in Section 3. A brief view of what has been called by (Balloni, Resende and Targowski, 2012) as "the characteristics of the participatory organizational ECO” can be used as a guide for balanced organizations that aim to benefit from its ECO's resources: 1) Open and lateral dissemination of know-how; 2) Freedom to voice contrary opinions; 3) Frequent face-to-face interaction; 4) Making tacit knowledge explicit; 5) Formal and informal organizational support mechanisms to manage the organizational ECO (Balloni, Resende and Targowski, 2012).

If we go back 150 years in history we shall see that competetive advantage was marked by the ownership of capital and assets such as natural resources. Today, the more important assets are those related to knowledge (Balloni, Bermejo, Holm and Tonelli, 2012). From the mid 1990s on, the investment in access to new ICT technologies evolved into a non-impeditive factor in face of the vertiginous decrease on their prices. Today, a great movement in the Industrial Revolution is towards appreciation of the intellectual assets, treating key specialists of an organization as a great competitive differential (Guevara and Dib, 2000; Mutka et al., 2009).

According to the Organizational ECOs approach (Kay, Regier, Boyle and Francis, 1999), complex systems are not explainable by linear relations of causality. These complex ECOs are considered Self-Organizing Holarchic Open Systems (SOHO), characterized by permanent interaction between their components, flexible hierarchies, constant reconfiguration of one organizational state to the other and the promotion of constant and adaptative learning.

The organizations are composed of complex organisms (people) who need to be understood through the knowledge of nature of their relations and within a determined context. It is the treatment of the organization as a living being, through a systemic view (think globally but act locally), which will enable the emergence of phenomena that shall enable the whole to be more than the sum of the parts of such being/organism (Balloni, 2010; Balloni and Targowski, 2010).

There is an opinion that organizations, known as relations' networks, cannot be reduced and "systematized". Also, the focus on people is not enough, since it is necessary to connect and contextualize them in the organization's cause. So, connecting and contextualizing people in the organization's cause may lead to a concept of the differential. To achieve this stage of organizational understanding, one must address the knowledge of the dynamics of the system as whole (Balloni, Bermejo, Holm and Tonelli, 2012). To achieve this stage of organizational understanding, one must address the knowledge of the dynamics of the system as whole: a Balanced Organizational ECO!

For countries in development, such as Brazil, to transform their condition, it is necessary, NOW, to advance their R\&D and local Collaborative ECO research efforts (Balloni and Targowski, 2010). This R\&D and local collaborative ECO research efforts must consider the principle of the Systemic View (thinking globally but acting locally), and it may be accomplished by the integration among one of these interdependent 
subjects: ecology, biology, communication, organizations, economy, education, communities, technology, culture and the human being (social-technical systems) - a balanced ECO approach.

Concerning Brazil (2010), inserted in the world-wide context, the wide scale changes occurring in the environment business has compelled the enterprises to radically modify their organizational structures and productive processes - a redesign of an old ecosystem. The main factors of these changes are the products' globalization, the wide scale of electronic processes use, the nature of the job (shifting from industry to the services sector) and the role of emergent markets as China, India and Brazil. Therefore, for the Brazilian enterprise, now and in the future, to maintain a sustainable position in the world-wide market, it is vital apply the approaches proposed here, using resources of Research and Development initiatives, such as the arrangement described in Section 3.

But, a question remains to be answered: "will management of IT, and the emergency of global partnerships, allow Brazilian enterprises to compete more effectively in the global marketplace, or will they be undermined by greater global competetion in their 'home territory'?" Here it is important to remember what Winston Churchill said (Balloni, 2010): "We shape our buildings; thereafter they shape us.” Therefore, the collaborative work space and socio-technical environment of tomorrow are being shaped today in our own country! Finally, it is important to draw the attention to new ways of organizations arising in the past few years and which provoked a reorganization of the social sectors. An important class of such new organizations is the so called Learning Community, promoting Education and the Social Asset with the development of individual qualities at people networks, dynamized by the electronic networks, leading possibly to new ways of acquaintance and relationship. Therefore, we must consider all technological possibilities available to us in Brazil, but we do not have to invent the wheel, but, rather to improve bearing.

Yet, according to Balloni (Balloni, Azevedo and Silveira, 2012), in this globalized world modern organizations need to understand that governance is, and always has been, the tonic of the management: there is an increasing importance of organizational ecosystems!

So, based on these lines above, this is why we pointed to Namitec case, described in the next section.

\section{The INCT/NAMITEC Initiative}

Networked organizations are critical in high technologies sectors such as microelectronics. Saxenian (1990) explains the resumption of competitiveness of Silicon Valley companies in the 1980's not by isolated companies' actions, neither by Government promotion. The author considers that the revival has been promoted by collaborative networks between specialized producers and a collective learning process.

In Brazil, the microelectronic industry is still an incipient one, reflected on its deficit trade balance: in 2009, the country has imported an amount equivalent to $\$ 3.2$ billions in semiconductor components; in the same year the exports reached only $\$ 57$ million (Swart, 2010). This has created a macroeconomic problem. As an example, the total of microelectronics components imports in 2009 represented 9\% of Brazil's commercial deficit in that year (Bampi, 2009). Due to the ubiquitous character of microelectronics components (that are increasingly present in every product and service of modern life), the natural tendency of this deficit is to increase, unless Brazil develops an indigenous microelectronics industry.

This fragility, in addition to the microelectronic industry's strategic and economic relevance, guarantied its inclusion in the public politics agenda. These policies are directed towards the formation of human resources, creation of integrated circuit project companies, such as CEITEC ${ }^{1}$, and setting up the regulatory mark.

The National Institute of Science Technology in Micro and Nanoelectonic Systems (INCT/NAMITEC), created in 2008, is a publicly funded initiative that aims to develop a network of applied research in the field of microelectronics in Brazil (Azevedo, Bueno, Balloni and Silveira, 2011). NAMITEC counts on educational and research institutes in the fields of physics, chemistry, computer science and electric/electronic engineering (137 researchers of 27 departments in 23 institutions in 13 Brazilian states). NAMITEC is managed by eight coordination areas, being five "hard" technological ones and three administrative.

One of NAMITE's administrative instances, the coordination for Knowledge Transfer to the Productive Sector, aims to develop strategies and actions aiming to enhance the transfers of technologies developed within NAMITEC activities, including direct contact with the companies and arrangement of meetings with business associations. Cooperation arrangements have been firmed with twenty eight public and private companies on the microelectronics business. However, the results of these cooperations are unclear, and most of NAMITECS researchers do not collaborate with any productive sector institution.

The interactions with the companies may be considered peripheral, since these are not institutions that directly and formally integrate the NAMITEC network. Despite the fact that the five technical areas of INCT/NAMITEC are integrated logically in a productive chain (from raw materials to final products), each institution develops interactions with the companies in an isolated manner (Azevedo, Bueno, Balloni and Silveira, 2011).

These characteristics indicate that in NAMITEC, the network emphasis is posed on the scientific pole (production of knowledge) and the technological pole (application of knowledge). It lacks, however, an active participation of the market pole, including the companies and users that materialize the innovation. In order for NAMITEC to promote innovative activities, it is necessary that the private companies assume a bigger role in this network. Furthermore, joint and coordinated action by the Government and the Education and Research Institutions are required so that the several organizations that are a part of the

${ }^{1}$ CEITEC is a Brazilian company focused on the development and production of application-specific standard products (ASSPs) for the RFID, wireless communications and digital multimedia market segments.

According to the Brazilian (Jornal da Ciência, 2011), the CEITEC Project started in 2001 and was inaugurated in 2010. It has not yet contributed in a significant way to solve the Brazilian external dependence in microelectronics. Neither the policies designed for attracting foreign investments in a chip factory has attenuated this macroeconomic problem (Swart, 2010; Azevedo, Bueno, Balloni and Silveira, 2011).

Yet, in according to the Brazilian (2011) CEITEC should start producing Integrated Circuits (IC) by 2012, and that prediction has been confirmed by JC (Jornal da Ciencia, 2012): the RFID Chip used for tracking cattle has born. The CEITEC company's design center, located in Porto Alegre, will develop chips that perform a strategic role in Brazil's microelectronics industry. The company's adjoining factory, now in the final stages of assembly and certification, is the first and only facility of its kind in Latin America to produce chips. CEITEC S.A. has a mission to place Brazil among the world leaders in advanced microelectronics (CIETEC NEWS, 2012). 
Brazilian microelectronic sector's organizational ECO ${ }^{2}$ acquire a beneficent convergence to the generation of useful innovations for the society as a whole. In order to help to overcome the difficulties of creating a microelectronic ECO in Brazil, NAMITEC's Coordination for Knowledge Transfer to the Productive Sector established a set of objectives, which unfold into macro-functions with the goal of beaconing management activities of technologic transfer in the NAMITEC network. In essence, these macro functions have as a final purpose to act on the ECO that the public and private institutions of NAMITEC are inserted, creating attractors to stimulate cooperation.

With these efforts, the goal is to induce the diverse actors in the ECO to develop collective and interactive learning in order to circulate the knowledge that has the potential of generating technologic innovations that strengthen the Brazilian microelectronic industry. The organizational ECOs concept adopted does not consider the technologic transfer activity a unilateral relation, in which knowledge flows from the Educational and Research Institution to the productive sector. Change to a desirable state depends on collective learning processes, highlighting the continuous organizational learning of all the components of the ECO: Network managers, researchers, demanding companies of NAMITEC's technologies and government institutions.

\section{Perspectives \& Conclusion}

The ideas presented in this paper consider that our world is fundamentally a socio-technical world, characterized by human and technological interactions, mediated by human organizations as that behave as organizational ECOs where interactions drastically affect people relationships in space and time.

Therefore, if we consider that the core knowledge is embodied in people's heads (tacit knowledge end their abilities to utilize them generate new knowledge, we cannot speak about knowledge/wise society without taking into account these interactions.

The interaction and alignment between the diverse components of SS suggests that we should consider these systems as organizational ECOs, complex systems composed by heterogeneous and self-organizing actors, where adaptive learning allow them to deal with constant change. This represents a change from an "anticipatory" management scheme to an "adaptive" and "participatory" management scheme, with open and lateral dissemination of know-how, communication mechanisms and face to face interactions.

However, management opposition persists, because even tough SS and organizational ECOs by nature enables collaborative decision-making and shared leadership, management topdown oriented has been reluctant to give up power and authority.

The central corner stone of a technocratic bureaucracy is that decision-making is top-down and implementation is bottom up. Amazingly, many postmodern organizational leaders still believe information is best kept in the minds of senior management who have been trained how to use it, make decisions, and implement policy. In this mechanistic model, managers pretend

\footnotetext{
${ }^{2}$ The challenges in integrating multiple actors towards an innovative action in Brazil, mainly in the private sector, are a part of the characteristics of our National Innovation System. The integration between universities/research institutes and companies are especially problematic (Velho, Velho and Saenz, 2004).
}

to know and employees pretend to cooperate.

Even though the idea of inter-organizational arrangements is not a new one ${ }^{3}$, we consider that an ecosystems view of organizations formed by multiple stakeholders can innovatively contribute not only to theoretical and academic discussions. It also can provide practical management practices, as proposed in a quite comprehensive way by (Kay, Regier, Boyle and Francis, 1999). In this sense, this paper relates the experience by the authors of implementing ecosystemic practices in a real inter-organizational arrangement, the INCT-NAMITEC.

Considering the ecosystemic approach two weaknesses can be pointed out in NAMITEC'S network described in Section 3: firstly, the lack of open and lateral dissemination of know-how, due to the poor communication mechanisms between researchers and interested companies. Secondly, face to face interaction is not as frequent as it should be: NAMITEC's researchers only discuss collectively network issues in Namitec workshops that occur twice a year. It is worth to mention that private companies do not attend or are invited to these workshops.

\section{Acknowledgements}

Thanks for Professor Dr. Andrew S. Targowski from Western Michigan Universit, Department of Business Information System (WMU).

\section{REFERENCES}

Ackoff, R. L. (1974). Redesigning the future: A systems approach to societal problems. New York: Wiley.

Aidemark, J. (2007). Is planning and socio-technical theory perspectives. URL (last checked 4 January 2010).

http://www.iseing.org/emcis/EMCIS2007/emcis07cd/EMCIS07-PDFs/ 571.pdf

Aidemark, J. (s.d.). What is actor-network theory? URL (last checked 4 January 2010).

http://carbon.ucdenver.edu/ mryder/itc_data/ant_dff.html

Akbari, H., \& Frank, L. (s.d.). Socio-technical theory. URL (last checked 5 January 2010).

http://www.fsc.yorku.ca/york/istheory/wiki/index.php/Socio-technica 1_theory

Azevedo, A. M. M., Bueno, A. K., Balloni, A. J., Silveira, M. A., \& Dias, M. D. N. (2011). Organizational ecosystems: Interaction and alignment towards innovation. URL (last checked 28 May 2012). http://www.intechopen.com/download/pdf/36242

Balloni, A. J., Azevedo, A. M. M., \& Silveira, M. A. (2012). Sociotechnical management model for governance of an ecosystem. International Journal of Managing Information Technology (IJMIT). http://airccse.org/journal/ijmit/papers/4312ijmit01.pdf doi:10.5121/ijmit.2012.4301

Balloni, A. J., Paulo, J. P. R., \& Andrew S. T. (2012). Brazil of the future: Strategizing with the socio-technical management approach. URL (last checked 28 May 2012). http://www.atiner.gr/papers/COM2012-0002.pdf

Balloni, A. J., Bermejo, P. H. S., Holm, J., \& Tonelli, O. A. (2012). Governance, sociotechnical systems and knowledge society: Challenges and reflections. URL (last checked 28 May 2012). http://www.irma-international.org/viewtitle/66970

Balloni, A. J., \& Targowski, S. A. (2010). Challenges and reflections on information, knowledge, and wisdom societies \& sociotechnical systems. URL (last checked 28 May 2012).

http://repositorio.cti.gov.br/repositorio/bitstream/10691/214/1/Paper_

${ }^{3}$ For instance, in 1849 the German Economist Friedrich List, considered the predecessor of the National Innovation Systems concept, published the book "National System of Political Economy", using a systemic approach to explain National Economies. 


\section{A. J. BALLONI ET AL}

JITCAR_ICIS7.pdf

Balloni, A. J. (2010). Challenges and reflections on knowledge society \& sociotechnical systems. URL (last checked 27 May 2012).

http://airccse.org/journal/ijmit/papers/0210ijmit3.pdf

Bampi, S. (coord.). Perspectives do investimento em eletrônica. Rio de Janeiro: UFRJ, Instituto de Economia, 272.

Bijker, W. E. (1989). The social construction of bakelite: Toward a theory of invention. In: W. E. Bijker, T. P. E. Hughes, \& T. J. Pinch, The social construction of technological systems. New directions in the sociology and history of technology (pp. 159-194). Cambrige, MA: MIT Press.

Bostrom, R. P., \& Heinen, J. S. (1977). MIS problems and failures: A socio-technical perspective, part II: The application of socio-technical theory. URL (last checked 5 January 2010).

http://www.iei.liu.se/is/edu/courses/725a04/kurslitteratur/1.107778/ MISproblemsII.pdf

Chang, E. (s.d.). Magnetic data storage and nanoparticles. URL (last checked 3 January 2010).

http://www.eng.uc.edu/ gbeaucag/Classes/Nanopowders/Application s/ErnieChang_NaMagneticMemory.pdf

Ceitec News (2012). RF and microwave systems-Brazil aims to jumpstart the development of the semiconductor industry. URL (last checked 2 August 2012).

http://www.ceitec-sa.com/en/news/rf-and-microwave-systems-brazilaims-to-jumpstart-the-development-of-the-semiconductor-industry

Dammasch, S. (2006). The system of Bretton Woods. A lesson from history. URL (last checked 4 January 2010).

http://www.ww.uni-magdeburg.de/fwwdeka/student/arbeiten/006.pdf

Dooley, M. P., Folkerts, D., \& Landau, P. G. (2003). An essay on the revived Bretton Woods system. URL (last checked 4 January 2010). http://www.nber.org/papers/w9971.pdf

Emery, F. E., \& Trist, E. (1981). Introduction to volume 1, first edition. Systems thinking (Volume 1), selected readings. Harmondsworth, Penguin.

Guevara, A. J. H., \& Catgarina, V. D. (2000). The ager of knowledge and the growing relevance of human and social capital. URL (last checked 1 August 2011).

http://in3.dem.ist.utl.pt/downloads/cur2000/papers/S26P05.pdf Last access 01/08/2011

Hughes, T. (1989). The evolution of large technological systems. In: W. E. Bijker, T. P. E. Hughes, \& T. J. Pinch (Eds.), The social construction of technological systems. New directions in the sociology and history of technology (pp. 51-82). Cambridge, MA: MIT Press.
Iansiti, M., \& Levien, R. (2004). The keystone advantage: What the new dynamics of business ecosystems mean for strategy, innovation and sustainability. Boston, MA: Harvard Business School Press.

Jornal da C. (2011). Primeira fábrica de chip do Brasil deve começar a produzir em 2012, diz Ministro. URL (last checked 28 July 2012). http://www.jornaldaciencia.org.br/Detalhe.jsp?id=80544

Jornal da C. (2012). Primeira fábrica de chip do Brasil deve começar a produzir em 2012, diz Ministro. URL (last checked 28 July 2012). http://www.jornaldaciencia.org.br/Detalhe.jsp?id=83524

Kay J., Regier, H., Boyle, M., \& Francis, G. (1999). An ecosystem approach for sustainability: Addressing the challenge of complexity. Futures, 31, 721-774. doi:10.1016/S0016-3287(99)00029-4

Mutka, et al. (2009). The impact of social computing on the EU information society and economy—European commission, joint research centre institute for prospective technological studies.

Pinch, T. J., \& Bijker, W. E. (1989). The Social construction of facts and artifacts: Or how the sociology of science and the sociology of technology might benefit each other. In: W. E. Bijker, T. P. E. Hughes, \& T. J. Pinch (Eds.), The Social construction of technological systems. New directions in the sociology and history of technology (pp. 17-50). Cambrige, Massachusetts: MIT Press.

Saxenian, A. (1990). Regional networks and the resurgence of Silicon Valley. California Management Review, 33, pp. 89-112.

Sörlin, S., \& Vessuri, H. (2007). Knowledge society vs. knowledge economy: Knowledge, power, and politic. New York: Palgrave Macmillan, Ltd.

Swart, J., Relatório da sessão "microeletrônica”. Parcerias estratégicas. Edição especial, 15, 267-280.

Targowski, S. A. (2003). Electronic enterprise: Strategy and architecture. London, Melbourne: IRM Press.

Targowski, S. A. (2011). Cognitive informatics and wisdom development: Interdisciplinary approaches. Hershey, PA: IGI Global.

Velho, L., Velho, P., \& Saenz, T. W. (2004). P\&D nos setores público e privado no Brasil: Complementares ou substitutos? Parcerias Estratégicas, 19, 87-129.

Warne, L., \& Hart, D. (1996). The impact of organizational politics on information systems project failure-A case study. http://www.computer.org/plugins/dl/pdf/proceedings/hicss/1996/733 3/00/73330191.pdf?template $=1 \& \operatorname{loginState}=1 \&$ userData=anony

Willinger, W., \& Doyle, J. (2002). Robustness and the internet: Design and evolution. URL (last checked 4 January 2010). http://www.maoz.com/ dmm/complexity_and_the_internet/robustne ss_and_the_internet_design_and_evolution.pdf 